\title{
THE COMMON GOOD OF THE COMPANY AND THE THEORY OF ORGANIZATION
}

\author{
Antonio Argandoña
}




\title{
THE COMMON GOOD OF THE COMPANY AND THE THEORY OF ORGANIZATION
}

\author{
Antonio Argandoña* \\ "No expression of social life - from the family to intermediate \\ social groups, associations, enterprises of an economic nature, \\ cities, regions, States, up to the community of peoples \\ and nations - can escape the issue of its own common good, \\ in that this is a constitutive element of its significance \\ and the authentic reason for its very existence" \\ (Pontifical Council for Justice and Peace 2004, 165)
}

\begin{abstract}
The concept of common good occupies a prominent place in political and social philosophy, yet it has had little impact on the theory of the firm. This is despite some recent attempts to resituate the theory of the firm on broader and therefore more fruitful anthropological and social foundations than those of traditional economic theory. The present study connects with other discussions of organization theory based on the ideas of Aristotle and Thomas Aquinas and is an attempt to explain how the concept of common good may be used to broaden the foundations of organization theory.
\end{abstract}

Keywords: Aristotle, Catholic social teaching, Common good, Company, Goods, Organization, Organization theory, Thomas Aquinas.

* Professor of Economics, "la Caixa" Chair of Corporate Social Responsibility and Corporate Governance 


\section{THE COMMON GOOD OF THE COMPANY AND THE THEORY OF ORGANIZATION}

\section{Introduction $^{1}$}

The concept of "common good" occupies a prominent place in the political and social philosophy of Aristotle (1941) and Thomas Aquinas (1981) and their followers and also in Catholic social teaching (Pontifical Council for Justice and Peace, 2004). Yet, with a few exceptions in the 1980s and 1990s (Argandoña, 1998; Kangas, 1983; Mahon and McGowan, 1991; Naughton, Alford and Brady, 1995; Velasquez, 1992), it has received scarcely any attention in theories of organization or studies of business ethics and corporate social responsibility.

So far this century, however, a number of works have been published aimed at making good that omission. Examples include Alford and Naughton (2001, 2002), Alford and Shcherbinina (2008), Arjoon (2000), Fontrodona and Sison (2006), Gates (2002), Kennedy (2007), Koslowski (2006), Melé (2002), Naughton (2004, 2006) and Sison and Fontrodona (2008). Some authors use the theory of the common good ${ }^{2}$ to criticize theories about the purpose or goal of the

\footnotetext{
${ }^{1}$ This study is part of the work of the "la Caixa" Chair of Corporate Social Responsibility and Corporate Governance at IESE.

2 The term "theory" or "model" is not entirely appropriate in relation to the common good. The concept of common good derives from an anthropological conception, has developed mainly from the sources just mentioned (Aristotle, Thomas Aquinas and Catholic social teaching) and has given rise to various theories, not all of which agree with one another. What I here call the "theory" of the common good is more properly described as a conception of man which is richer than the one that underlies the usual theories of human behavior, society, organizations and the economy, and which therefore is capable of sustaining a critique of those theories and a proposal for revising them.
} 
company; both those that emphasize shareholder value maximization and those that focus on the satisfaction of stakeholder interests. Others suggest an interpretation of the stakeholder model, which they try to make compatible with the conception of the common good. Yet others propose a "model" of the common good as an alternative to traditional economic models of the firm.

There is a danger that these works will have very little impact on the conventional theory of the firm or organization. The paradigm they propose is too different from the conventional one, with which they appear to have little in common. Scholars of economics and management are likely not to understand the criticism being made of them by theorists of the common good or not to take much notice of it because it uses categories that are unfamiliar to them. And even if they understand the criticism and find it relevant, they may not know how to translate the categories of the common good model into the traditional categories of their economic, social or psychological models. On the other hand, those trained in the philosophical tradition of Aristotle and Thomas Aquinas or in the principles of Catholic social teaching will have difficulty translating their anthropological and social models into categories comparable with those of organization theory.

This non-meeting of minds seems yet another example of the "debate between fundamentally opposed standpoints" of which Alasdair MacIntyre spoke, a debate that is "inevitably inconclusive" because "each warring position characteristically appears irrefutable to its own adherents; indeed, in its own terms and by its own standards of argument, it is in practice irrefutable. But each warring position equally seems to its opponent to be insufficiently warranted by rational argument" (MacIntyre, 1990, p. 7). Only "someone who inhabits both alternative conceptual schemes, who knows and is able to utter the idiom of each from within" (MacIntyre, 1990, p. 114) can resolve this impasse.

It would be arrogant of me to claim that capacity. My purpose in this discussion is much less ambitious: it is to present the model of the common good in a way that brings it closer to the categories of traditional theories of organization. To do this, I will draw mainly on certain previous attempts to use an Aristotelian and Thomist-based anthropology to construct a theory of organization coinciding, in essence, with what I here call the theory of the common good (Pérez López, 1991, 1993; Argandoña, 2008a, b, c; Rosanas, 2008a, b).

In what follows I will use the concept of good as a foundation that is, to a greater or lesser extent, shared by the different positions, explaining the variety of 'goods' that appear and that converge in the concept of common good and its attributes. After that, I will discuss how organization theory treats these goods and make some proposals about the common good of organizations, ending with the conclusions.

\section{Goods}

The concept of "good" lies at the very foundation of economics. Usually it refers to useful, scarce and therefore economically valuable (natural or man-made) goods that people believe will satisfy their needs. The moral philosophy of Aristotle and Thomas Aquinas also takes as its starting point the concept of "good", which Aristotle defines (or rather, describes) at the beginning of his Nichomachean Ethics as "that at which all things [or all people] aim" (Aristotle, 1941, p. 935). So it would seem we can start our analysis from a certain conceptual convergence (Shionoya, 2008, p. 73). Is that true? 


\section{Goods, needs, satisfactions and goals}

Traditional economics starts from the assumption that the economic agents have "needs" (or "desires") and that there are "goods" capable of satisfying those needs. Let us say a person has certain needs and requires an income to satisfy them, so he decides that the best way to obtain an income is by accepting a job, in which he undertakes to perform certain activities for a certain length of time under the command of another person in exchange for a salary. For this person, the salary will be a good in the economic sense, but also in the sense that Aristotle gives the term, as the person "seeks" the salary precisely in order directly or indirectly to satisfy those needs. We shall call this an "instrumental" good. ${ }^{3}$

Besides remuneration, the job will also produce other "goods" for the agent: the satisfaction of doing interesting work, the knowledge he acquires and the capabilities he develops, relationships with other people, the moral habits he develops, and so on. Some of these are recognized as goods in economics; others are not, yet deserve to be, as they are things the agent seeks or desires. ${ }^{4}$ We shall call these "final" goods. ${ }^{5}$

In the philosophical theories we are discussing here, this is a classic distinction that will enable us to broaden the economic concept of good. We still feel it can be improved, however, and so propose to distinguish three types of goods: ${ }^{6}$

1) "Extrinsic" goods. Extrinsic goods are external to the agent. They include material goods (earlier classified as instrumental; in our example, the salary) and some intangible goods (the recognition and approval of bosses or colleagues, for example), which are sometimes regarded as final goods. Extrinsic goods are goods insofar as they satisfy needs or desires: the agent forms an expectation of what his situation will be once he has achieved these goods and considers that situation desirable; this then becomes one of the motives of his action.

2) "Intrinsic" goods, which are "inside" the agent (albeit as a result of the agent's interaction with the outside world). They include the satisfaction of a job well done (which is not the same as external recognition, which is an extrinsic good), the acquisition of knowledge, the development of capabilities, or simple interaction with other people. Many of these are what we earlier termed final goods. They, too, meet a need, at least in a broad sense: the agent hopes or

\footnotetext{
${ }^{3}$ In the common good literature this type of good is variously referred to as "instrumental", "foundational", "extrinsic", "sought in order to obtain other goods", "proximate”, etc.; cf. Kennedy (2007, p. 173), Alford and Naughton (2001, pp. 40 and 257, note 8), (2002, pp. 35-36), Sison and Fontrodona (2008, p. 3), Yuengert (2001, p. 2). The classifications and definitions do not always coincide, but they have a good deal in common.
}

\footnotetext{
${ }^{4}$ Moreover, "the main issue [in economics] is almost confined to the total quantity of the good (allocative efficiency) without regard to the differences of the good among individuals (distributive justice) and the differences in the quality of the good (human excellence)" (Shionoya, 2008, p. 74).

5 These, too, are given a variety of names: "final”, "excellent”, "intrinsic”, "inherent”, "sought for their own sake”, "ultimate", etc. (see references in the previous note 3).

${ }^{6}$ Here I follow the ideas of Juan Antonio Pérez López $(1991,1993)$. Although Pérez López did not explicitly formulate a theory of goods, his model is compatible with the one I describe here. Cf. also Argandoña (2008a, b, c), Rosanas (2008a, b).
} 
expects the job to afford him satisfaction or allow him to learn something useful, although he cannot know exactly how much he will enjoy it or how much he will learn.

3) "Transcendent" goods, which the agent seeks for others, not for himself, although they also have an effect on the agent in that they allow him to develop the means to continue to act with the same motivation, that is, moral habits or virtues (Pérez López, 1991). They, too, are goods as defined by Aristotle because the agent desires or "seeks" them. But they do not satisfy needs, at least not as understood by economics. Yet if we distinguish between material needs ("which are satisfied from outside the subject" through extrinsic goods), cognitive needs ("linked to the capacity people have to do things and get what they want," which are satisfied with intrinsic goods) and affective needs ("linked to the achievement of appropriate relationships with other people," which are met through transcendent goods; cf. Pérez López, 1993, p. 59), transcendent are a legitimate extension of the concept of good used in economics. ${ }^{8}$

In our view, this classification better describes the content of what we earlier called instrumental and final goods. Ultimately, transcendent goods (moral habits or virtues) are quintessential final goods insofar as they radically change a person's capabilities and make him a better person and better able to achieve his goals, which intrinsic goods do not. ${ }^{9}$

The terminology we have used in this section suggests that there is a hierarchy among the different types of goods, final (and specifically transcendent) goods being the highest. It is important that this be understood correctly, however. All the types of goods considered here may be legitimate. Insofar as an agent seeks them, all may set the decision-making process in motion. Moreover, the pursuit of instrumental and extrinsic goods is probably the main driver of human actions, especially in the market and in economic organizations. So instrumental

\footnotetext{
7 This type of outcome is not what is pursued through altruistic behavior as traditionally treated in economics: an altruist derives personal satisfaction from another person's good, which makes altruism an extrinsic (other people's appreciation) or intrinsic (own satisfaction) good.

${ }^{8}$ Finnis (1983, p. 31) expresses the same idea in a different way: "I can use the phrase 'my wants' to refer (...) to my present desires conceived of as states of my present being, my will, psyche or experience... to which present states correspond those future states of my being, psyche or experience which we call 'satisfactions'”. This refers to extrinsic and also, to some extent, intrinsic goods. But also "I can use the phrase 'my wants' to refer (...) to my objectives, i.e. the things I want to get, to do, to have or to be" (Finnis 1983, p. 31), which clearly applies to transcendent goods. Similarly, the "term 'satisfaction', like its cognate 'satisfying', differs widely in its connotations from the term 'satisfactory'. For the satisfactory is not, essentially, what is satisfying or creates satisfactions; rather it is what is suitable for a purpose (or even, simply, suitable, i.e. good). And the purposes we intelligently conceive and pursue (...) cannot be assumed to be exclusively, or even primarily, concerned with getting us satisfactions” (Finnis 1983, p. 31).

${ }^{9}$ Alford and Naughton (2001, p. 36) end their discussion of what they call excellent goods and we have called final goods with a clear reference to transcendent goods, that is, virtues: "What we mean by an excellent or inherent good are those internal qualities which develop between human persons and within communities, such as friendship, personal motivation, and moral self-possession. The goods in the workplace are often described in terms of virtues such as justice, prudence, courage, solidarity and patience, that is, internal qualities that foster the growth of people and contribute to a community of persons" (my emphasis).
} 
goods are not to be scorned. ${ }^{10}$ Final goods are excellent because they are the condition for consistency of decisions in individuals and organizations alike: however correct a decision aimed at satisfying a short-term need by using instrumental goods may be, if it jeopardizes future decision making (that is, if it undermines a person's moral quality), it will be harmful in the long run, so those goods will not be true goods (Argandoña, 2008b, Pérez López, 1993, p. 54).

\section{"Use" or "consumption" of goods}

The theory of the common good does not usually distinguish, at least not explicitly, between the "demand", "use" or "consumption" of goods, on the one hand, and the "supply", "generation" or "production" of goods, on the other. In economics the "demand" side is crucial because a good is only a good insofar as it is valued or appreciated by the person who demands, uses or consumes it, regardless of how much it cost to produce. From this point of view, in economics distinctions are made between different types of goods based on two criteria: rivalry and exclusion. A good is "rival" if its use by one person prevents its use by another (if I eat a fish, nobody else can eat it); otherwise, the good is non-rival (the fact that I watch a sunset does not prevent other people from also watching it). And a good is "excludable" if it is possible to prevent a person from enjoying its benefits (the owner of a toll highway can prevent drivers who have not paid from using it); otherwise the good is nonexcludable (as in the case of a non-toll highway, at least so long as it is not congested) (Mankiw, 1998, p. 210).

Using these criteria, economics distinguishes four types of goods: "private goods" (rival and excludable, e.g., a fish), "club goods" (non-rival and excludable, e.g., cable television), "common goods" (rival and non-excludable, e.g., ocean fishing) and "public goods" (non-rival and non-excludable, e.g., a mathematical theorem).

In the philosophical tradition of Aristotle and Thomas Aquinas this detailed distinction is not usually made; instead, goods are divided into "private", "individual" or "particular" goods, on the one hand, and "common" or "public" goods, on the other (Alford and Naughton, 2001, p. 50; 2002, p. 45, note 21). The criterion used to make the distinction is that of rivalry in use or enjoyment. Private or particular goods cannot be "shared" by other people. They therefore include what in economics are known as private goods (the fish eaten by one person cannot be eaten by another) and common goods (all of a town's inhabitants have access to the water supply from a municipal water tank, but the water drunk by one person cannot be drunk by another). What the Aristotelian-Thomistic tradition calls common goods include what economists call public goods (everybody can share knowledge of a theorem) and club goods (everybody who has access to a cable television signal can receive it).

Extrinsic goods, therefore, will be private or particular (the salary received by one employee cannot be received by another). Intrinsic goods will usually be common (two employees can share the personal satisfaction of working in the same team and the knowledge acquired while

\footnotetext{
${ }^{10}$ Alford and Naughton (2001, p. 40) call what we have called instrumental goods "foundational" goods to highlight the fact that "in some ways, foundational goods, like profits or efficient methods, are the most important because they directly support the economic viability of the firm in a market environment. They are necessities, and they influence everything else the firm undertakes." Cf. also Pérez López (1993, pp. 115-116). That is why I do not consider it appropriate to identify, as some authors do, "instrumental" goods with "apparent" goods (as opposed to "real" goods, the latter being what we have called final goods), as if they were not really goods at all (Arjoon, 2000, p. 169).
} 
doing so). ${ }^{11}$ And transcendent goods are always common (while it may seem as if virtues are acquired for the perfection of the agent himself, they always relate to others and have their meaning in that social relationship).

These descriptions do not have a predetermined moral dimension, however: the acquisition of a private good, such as a fish, may be a virtuous act, carried out to satisfy hunger or to give the fish to a hungry person (for whom it will also be a private good); or it may be an immoral act, carried out merely to deprive someone else of the good. Likewise, the "consumption" of a good may be an individual or a communal act: I may eat the fish on my own or in the company of my friends (although even then the piece of fish I eat cannot be eaten by anybody else); likewise, I can use a mathematical theorem for a strictly personal purpose, selfish or otherwise, or share it with other scholars.

And the fact that Catholic social teaching sets great store by common goods does not mean that it undervalues private goods, given their instrumental, yet very important, role in the wellbeing of people and the progress of society. The emphasis is invariably on the social dimension of the use or consumption of these goods, insofar as a person feels called to manage them "responsibly and together with others" (Pontifical Council for Justice and Peace 2004, n. 20; cf. also n. 158). What in this teaching is called the "principle of the universal destination of goods" (nn. 171-184, 328-329) indicates that goods (material and non-material, including knowledge and personal capabilities and, of course, moral habits) have been created for the benefit of all people. We shall come back to the characteristics of common goods in human organizations later.

\section{"Production" or "generation" of goods}

The "production" or "supply" of goods may be either "private", "individual" or "personal", on the one hand, or "public", "social" or "common", on the other. If I wish to obtain a private good (a fish, for example), I can catch it myself (an individual activity), or I can buy it in a supermarket (which entails an interaction with other people, however limited and impersonal), or I can catch it in community as an employee of a fishing company or a member of a fishermen's club. Similarly, I can obtain a transcendent good personally (I can acquire the virtue of patience by fishing on my own) or in community (I can do it within the framework of interpersonal relations, in my family or in a company).

The theory of the common good has not developed this classification in relation to the "production" of goods of any kind, but it does emphasize the social or communal dimension of the production process (Melé, 2002). Even when a person fishes on his own she is still part of a dense network of social relationships: somebody taught her to fish, made the rod, sold her the bait, and so on. This is even truer of intrinsic and transcendent goods, where the learning (both operational learning, i.e., what is learned in producing intrinsic goods, and above all evaluative learning, i.e., what is learned in producing transcendent goods) takes place precisely within the framework of social relationships. Catholic social teaching adds two important points: first, the "gift" and gratuitousness of goods (material or otherwise, and also of human capabilities) received from God (Pontifical Council for Justice and Peace 2004, nn. 20 and 428) and, second, the fact that men and women receive many, if not all, of these goods thanks to the work of their ancestors and the collaboration of society, so that "they are debtors because of those

\footnotetext{
11 There can also be unshared, intrinsic private goods, such as the satisfaction a person obtains from "bowling alone" (Putnam, 2000), but in social activities that satisfaction is likely to have to do, one way or another, with the participation of other people.
} 
conditions that make human existence liveable, and because of the indivisible and indispensable legacy constituted by culture, scientific and technical knowledge, material and immaterial goods and by all that the human condition has produced" (n. 195).

For all these reasons, the theory of the common good emphasizes that the company is a "community of persons", because the person is essentially a social being who needs others not only to satisfy his or her own needs and subsist but above all to develop as a person and be happy: life with others is part of the very idea of happiness (Kennedy 2007, 53). "A business cannot be considered only as a 'society of capital goods'; it is also a 'society of persons' in which people participate in different ways and with specific responsibilities, whether they supply the necessary capital for the company's activities or take part in such activities through their labour" (Pontifical Council for Justice and Peace 2004, n. 338). ${ }^{12}$

In any case, presenting the company as a community should not make any difference to the view that economics has of it: the company that economics describes is already a community of persons. There is, however, an important difference: economic theory reduces the human component of the company to certain partial aspects, such as contractual relationships or purely economic motivations (the pursuit of extrinsic goods, in our terminology), while the theory of the common good broadens this view to encompass not only dimensions such as profitability, efficiency and competitiveness (which are entirely legitimate, indeed indispensable, in any economic institution), but also others such as unity and consistency, which are necessary for persons to develop and, therefore, for the company to flourish and even merely subsist (Argandoña, 2008b; Pérez López, 1993).

\section{Anticipated and realized goods}

When a person has a need (when she is hungry, for example), she begins a decision process which leads to an action aimed at satisfying that need by obtaining a good (food). Decision theory assumes that the agent "anticipates" the satisfaction she will derive from the various action alternatives available to her (different foods, for example, or different ways of obtaining it) and chooses the one she prefers (Pérez López, 1991; cf. also Argandoña, 2003, 2005; Ariño, 2005). The good this person aims to obtain is therefore a "potential" or "anticipated" good (Kennedy, 2007, p. 173; Sison and Fontrodona, 2008, p. 9). What the person wants, however, is the "actual" or "realized" good, which is what satisfies her need (if it is an extrinsic good) or perfects her as a person (if it is a transcendent good: "something that perfects or fulfills a living being (such as a human being)”, Alford and Naughton, 2001, p. 39; cf. Alford and Shcherbinina, 2008, p. 19).

The anticipated good is what moves a person to act. ${ }^{13}$ But once an action has been performed, the outcome may not be as anticipated. The food may not satisfy the person's hunger or may have unforeseen effects that make the person's final situation worse (or better) than anticipated. In any case, people learn from their actions. They learn in evaluating extrinsic goods; above all, they learn in evaluating intrinsic goods (operational learning) and even more in evaluating transcendent goods (evaluative learning) (Pérez López, 1993). As a result of what they learn, something they may have considered a good a priori they may no longer consider a good ex post.

\footnotetext{
12 This sentence is a literal quotation of John Paul II (1991, n. 43).

${ }^{13}$ As there are three types of goods (extrinsic, intrinsic and transcendent), so there are three types of motivation, named likewise. Cf. Pérez López (1991, 1993).
} 
Philosophers of the common good often refer to the ultimate good of man. Aristotle sites this ultimate good in eudaimonia, which may be rendered as happiness or, better, human development or flourishing, be it corporal, cognitive, emotional, esthetic, social, moral or spiritual (Alford and Naughton, 2001, p. 75). The reference to this ultimate good seems out of place in economics, whether because economics postulates that the pursuit of happiness is a personal matter for each agent or because happiness, as an object of human action, is not an operational goal.

Yet, precisely because the ultimate good does not consist of a predetermined outcome that can be achieved by following a set of rules but depends on what the subject has learned, there is a point in recognizing the importance of this ultimate good. The strategy for achieving this ultimate objective must consist of setting in motion learning processes that enable (or at least do not prevent) people from gradually identifying what happiness consists of (Pérez López, 1991, p. 54; Argandoña, 2008a). What we earlier called human development or flourishing is precisely that: the development of the necessary capabilities to become the person we want to be and act the way we want to act (Kennedy, 2007, p. 53). And that depends partly on what we have called extrinsic goods (a person cannot flourish or even survive without a minimum of extrinsic goods), but above all on intrinsic and, more importantly, transcendent goods.

What the recognition of the goods we described earlier as being of a "higher" nature adds to the traditional goods of economics is no less than the establishment of the "necessary conditions" for human activity not to be counterproductive or inconsistent with the development of the person - and naturally also with the survival and development of human organizations (Argandoña, 2008b).

\section{Goods in organizations}

We are now in a position to better understand the role of the variety of goods in organization theory. As we saw earlier, people who become part of an organization as owners, managers or employees do so because they seek certain goods: extrinsic (profits, wages, salaries), intrinsic (satisfaction, career opportunities, social relationships, learning opportunities, the chance to develop capabilities) and transcendent (virtues). To economic theories of the organization, the theory of the common good adds this greater variety of goods - and, consequently, more complex decision and learning processes and new conditions for the organization and the people who work in or with it to flourish (Pérez López, 1993).

Organizations use private, collective and common goods: extrinsic (physical capital, facilities, financial resources, labor), intrinsic (knowledge, culture, technology, organization) and transcendent (the virtues of its members). With these goods they obtain other private and common goods: extrinsic (the goods and services produced), intrinsic (new knowledge, capabilities, culture, technology, etc.) and transcendent (a new level of virtue in their members). ${ }^{14}$

Organizations use these goods to satisfy needs. First, they use them to satisfy the extrinsic needs of their customers, to whom they provide the goods and services they have produced in exchange for the financial resources they need, which they then use, once all the contractual

\footnotetext{
${ }^{14}$ And also "negative" goods, "false" goods or "evils": pollution, congestion, boredom, vices, etc., which we will take for granted in what follows. On the possibility of "negative learning” in organizations, cf. Pérez López (1991, pp. 49-71).
} 
(raw materials, interest, rents, etc.) and non-contractual (taxes) costs have been covered, to satisfy the extrinsic needs of their owners, managers and employees (profit, wages, salaries, etc.). In performing this function, companies must generate sufficient revenue to allow them to cover contractual and non-contractual costs and satisfy the extrinsic needs of their members on at least the same terms as the market (Pérez López, 1993, ch. 9).

Second, companies use all these resources to satisfy the intrinsic needs of their members. They must afford their employees a minimum of job satisfaction, operational learning, etc., so that they want to continue to work together in the organization, while at the same time enabling their members to develop their ability to better do what the company does; that is, improve its distinctive capabilities (Pérez López, 1993, ch. 10).

Lastly, organizations must motivate their members to learn to act always with a view to satisfying the needs of others: customers, owners, managers, employees, suppliers, the local community, and so on. If they do this, the members are able to obtain transcendent goods in the organization (i.e., they are able to develop moral virtues) that will allow them to flourish as persons, which is also a condition for the company to flourish as an institution. (Pérez López, 1993, ch. 10).

All this is, or should be, part of organization theory (Pérez López, 1991, 1993; Argandoña, 2008a, $\mathrm{b}, \mathrm{c})$. And as we have shown, not only is it not incompatible with a theory of the common good applied to companies; it is the very same theory under another name and broadened.

\section{Private and common goods in organizations}

The theory of the common good was developed with the idea not of limited communities (families, companies, civil associations), but of society as a whole - "political society", the "polis" or the "nation". Based on the principle that "far from being the object or passive element of social life' the human person 'is rather, and must always remain, its subject, foundation and goal" (Pontifical Council for Justice and Peace 2004, n. 106), ${ }^{15}$ there developed the idea that there is such a thing as the common good of society, which in Catholic social teaching is defined as "the sum total of social conditions which allow people, either as groups or as individuals, to reach their fulfillment more fully and more easily" (Pontifical Council for Justice and Peace 2004, n. 164). ${ }^{16}$ In view of what we expounded earlier, however, that common good is not one, but an intricate web of common goods of differing scope and level, each ordered to others, so as to form the higher common good of human society (Kennedy, 2007, p. 172). That is why the common good is also said to be "the good of all people and of the whole person" (Pontifical Council for Justice and Peace 2004, n. 165).

Given the centrality of the person in the theory we are discussing, the common good of society will also be the purpose of society: beyond any specific functions such as meeting certain priority needs (health, education, social welfare, etc.), keeping law and order, providing services (administration of justice, defense, policing, etc.) or redistributing income and wealth, society exists to provide that "sum total of social conditions which allow people, either as groups or as individuals, to reach their fulfillment more fully and more easily", in accordance with the

\footnotetext{
${ }^{15}$ The quotation is from a radio message by Pius XII, broadcast on 24 December 1944.

${ }^{16}$ The sentence quotes literally from the Second Vatican Council's Pastoral Constitution Gaudium et Spes (1965, n. 26).
} 
definition given previously (Pontifical Council for Justice and Peace 2004, n. 164). This general common good is what people and communities (n. 167) and, above all, the state (n. 168) must respect and promote as a necessary condition for society to perform its function. ${ }^{17}$

Voluntary, specialized human communities (companies, associations, clubs, foundations, etc.) pursue very different ends, specific human goods, which must be compatible with the development or perfection of people but, unlike the goods pursued by the family or civil society, do not seek it directly (Kennedy, 2007, p. 175; Alford and Naughton, 2001, p. 52). Therefore, before we talk about the common good of these specialized communities (which will be different for each one), we need to talk about the common goods they create. ${ }^{18}$

The starting point of our analysis is the decisions people make. Let us say an agent seeks one or more goods (which at this stage will be potential or anticipated) for himself or others (goods seen from the perspective of their use or enjoyment). As we said, the expectation of obtaining the goods motivates the person to act. He brings certain goods (extrinsic, intrinsic and transcendent: time, money, effort, knowledge, capabilities, virtues, etc.) into play in this personal action and coordinates his action with those of other agents (goods seen from the perspective of their production) in order to achieve a common goal. As a result of his action, the agent expects to obtain the goods he was seeking (now actual or realized), but he is not sure that he will always obtain them. In addition, he will achieve other results, other goods (or their opposites, evils), which he may or may not have sought or foreseen: extrinsic (other people's gratitude), intrinsic (satisfactions, operational learning) and transcendent (evaluative learning or moral habits, that is, virtues or their opposite, vices).

We are assuming that each agent performs his personal action within a community or organization. The community is made up of a group of people (in a company, the owners, managers and employees, and possibly other stakeholders) who have agreed to engage in an activity together in order to achieve results which could not be achieved, or not so easily, without such collaboration. As we said earlier, the motives that prompt each person to engage in the common activity (the goods that each seeks to achieve) will be very different, yet their actions have a common purpose. Thus, to people's needs (the goods they seek) and actions (the goods they contribute), the organization adds a common goal and the coordination of actions to achieve it (Pérez López, 1993, pp. 14-15).

Coordinated action within an organization thus gives rise to a set of private and common goods that are not mere byproducts because "underlying any genuine collaborative action (as opposed to an aggregate of individual actions aimed at the same good, such as a gold rush) there must be at least a potential common good" (Kennedy, 2007, p. 173; cf. also Pontifical Council for Justice and Peace 2004, n. 150).

\footnotetext{
${ }^{17}$ In Catholic social teaching, the ultimate common good of man is God (Aquinas 1950, c. 13, n. 634; cf. Sison and Fontrodona, 2008, p. 7). In a Christian-inspired organization theory, therefore, the concept of common good will be no different from the one discussed here, but it must always be open to that "transcendent dimension, which moves beyond the historical dimension while at the same time fulfilling it" (Pontifical Council for Justice and Peace 2004, n. 170).

18 In what follows I have drawn on Alford and Naughton (2001, 2002), Alford and Shcherbinina (2008), Argandoña (1998, 2005b), Arjoon (2000), Fontrodona and Sison (2006), Kennedy (2007), Melé (2002), Naughton et al. (1995), Pontifical Council for Justice and Peace (2004), Sison and Fontrodona (2008) and Yuengert (2001), among others.
} 
Therefore, the treatment of goods in organization theory must be seen as one, because the "production" process of the different types of goods is one. First, as regards potential or anticipated goods: the agents simultaneously seek extrinsic, intrinsic and transcendent private and common goods and therefore have a plurality of motivations (Pérez López, 1993, p. 55; Alford and Naughton, 2001, p. 51; Kennedy, 2007, p. 175). Second, as regards the resources employed: the agents contribute goods of all kinds, extrinsic, intrinsic and transcendent. Third, as regards the process by which goods are produced, in which all the goods contributed by all the agents in the organization play a role. And lastly, as regards the results, that is, the actual or realized goods, which also are of all the kinds described above.

A corollary of this is that private goods are part of common goods, at least insofar as private goods (both those contributed and those sought) motivate the agents to collaborate (Kennedy, 2007, p. 177). ${ }^{19}$ It makes no sense, therefore, to contrast private goods with common goods (Argandoña, 1998, 1096) nor to describe private goods as selfish and common goods as altruistic (Alford and Naughton, 2001, p. 67). ${ }^{20}$

All goods, common goods in particular, are "produced" by people acting in human communities: the common good "arises out of common, shared activity, just as the good of each human being (...) arises through his or her own activity" (Alford and Shcherbinina, 2008, pp. 19-20; cf. Pérez López, 1991, pp. 19, 25). They do not consist of the joint action itself, however, but of the intrinsic and transcendent goods that result from it.

In principle, it is assumed that there must be a certain proportion between the private goods that a person contributes to the organization (her labor, for example) and those she receives from it (her remuneration). This is obvious in the case of extrinsic goods: owners will try to ensure that the final value of their property is greater than what they contributed initially, plus the opportunity cost (what they would have earned in another similarly risky activity), while employees will try to ensure that the salary they receive is at least equal to what they could have earned in a similar job. Such proportionality is not necessarily to be found in intrinsic and transcendent goods, however. For example, an employee may create new knowledge in the organization and benefit from it; but other employees and perhaps even people unrelated to the company will also benefit and there does not have to be any remuneration for these externalities. The same occurs, with all the more reason, in the case of transcendent goods: an agent develops his virtues while working with the organization and those virtues benefit others

\footnotetext{
${ }^{19}$ The following is an illustrative example of the relationship between types of goods, based on Sison and Fontrodona (2008, p. 9). The motivations that lead the citizens of a town to work together to build a water reservoir will probably include the desire of each citizen to ensure access for himself to the private good of water (extrinsic motivation), although some may also (or even primarily) seek the benefit of others (transcendent motivation). In any case, the joint action generates not only private goods for all (water), but also a set of common goods, such as the exercise of distributive justice, social harmony and a spirit of cooperation in the community. The water in the reservoir is not a private good, but a collective one (Argandoña, 1998, 1096), that is, it belongs to the community. But it becomes a private good when each citizen appropriates part of it for his own consumption, so that, if the number of participants increases, each person's share is reduced. The common goods created do not, however, diminish when the number of participants increases - although they may diminish, or even disappear, if there are disputes, enmities or injustices.

20 The private goods must, however, be authentic human goods and must be sought by morally correct means (Kennedy, 2007, p. 177; Sison and Fontrodona, 2008, p. 26; Pérez López, 1993, p. 102).
} 
agents, because virtues are essentially other-oriented; for the organization they are a form of “moral capital" (Sison, 2003)..$^{21}$

The extrinsic goods generated in the organization belong to people. The transcendent goods also belong to people because they are perfections or plenitudes achieved by them (knowledge, capabilities, virtues), but as they are a human perfection or fulfillment achievable by a community, the community's members all share in them, both as a community and singly, in their persons ${ }^{22}$ even though not all contribute to the common goods in the same way nor share in them in the same measure or proportion. ${ }^{23}$

Private goods must be subordinate to common goods in the sense that the loss of transcendent goods in an organization will eventually destroy the organization's consistency and ultimately its ability to provide goods of any kind for its members (Pérez López, 1993; Argandoña, 2008b; Alford and Naughton, 2001, p. 51; MacIntyre, 1988, ch. 8). This is not to say that any common good of the community is superior to any private good of one of the community's members, because "the beginning, the subject and the goal of all social institutions is and must be the human person" (Second Vatican Council 1965, n. 25), so the main criterion must always be the person, not the community, which is at the service of the person, and because the definition of common good given earlier itself refers to allowing all people to "reach their fulfillment more fully and more easily" (Second Vatican Council 1965, n. 26).

The concept of common good also has a normative dimension, which implies that the members of an organization have a commitment or duty to promote "all the goods necessary for integral human development in the organization" (Alford and Naughton, 2001, p. 45). ${ }^{24}$ However, promoting these goods does not consist of establishing a list of actions that must be taken as a necessary or sufficient condition to achieve the common good in an organization, partly because in everything they do people acquire new knowledge, new capabilities, attitudes, values and virtues, so that what they will be able to do in the future will be different from what they were able to do in the past and from what we can foresee them being able to do with the information currently available. Creating those conditions in an organization therefore consists of creating capabilities: operational capabilities (the organization's specific competencies) and evaluative capabilities (its members' moral virtues) (Pérez López, 1991, pp. 53-54).

\footnotetext{
${ }^{21}$ From what we have said so far it is obvious that the common good of a company is not the volume of its sales, production, wealth or profits, nor the sum of the interests or goals of its members or a majority of them, nor the material well-being they achieve, nor a supposed "general interest" of theirs (such as the company's prosperity), etc.

${ }^{22}$ A common good is not "a good of the whole that disregards the good of its members" (Alford and Naughton, 2001, p. 41).

${ }^{23}$ The organization itself and the laws and rules that govern it make it possible for a common good to be created, but they are not themselves the common good. Although earlier we defined the common good as a set of conditions, it is more than those conditions, as "it relies on the 'subjective community of action' that develops out of participation" (Alford and Naughton, 2001, p. 185).

24 Although this function has traditionally been attributed to those in positions of authority (Alford and Naughton, 2001, pp. 41-42), this is a duty that affects everybody in the organization in some way: there is no distinction between "principal" and "agent" (Pérez López, 1993; Rosanas, 2008a).
} 


\section{The common good of the company}

Earlier, we talked about the common goods that are created in human organizations. In a company, which is a contingent and limited organization, these goods will also be contingent and limited to what a particular human group is capable of achieving in its specific circumstances. What goods are achieved will depend at any given time on the resources available, mainly on the intellectual, moral and affective quality of the organization's members. Depending on how far they have developed as a result of what they have learned from doing things in the organization, these people will be able to create more or fewer goods, and goods of greater or lesser scope. Moreover, the goods will never be acquired once and for all. At the very least they will have to be maintained and they can always deteriorate or be lost. ${ }^{25}$

We have already seen that it makes sense to talk about the common goods of a company, but is there such a thing as "the" common good of a company? We shall approach the subject in a roundabout way. If the common good of the company exists, it cannot be identified with the common good of society (that is, with the promotion of conditions that allow people to reach their fulfillment more fully and more easily, according to the definition given previously), because it is of a different nature. Companies are voluntary, specialized communities, created to achieve certain legitimate human goods (Kennedy, 2007, p. 176). As general human communities they must contribute to (i.e., at least not prevent and as far as possible promote) the full human development of their members. And as specific communities they must be judged according to the quality and importance of the goods they provide (namely, the satisfaction of certain needs of their owners, employees and managers by producing useful goods and services that satisfy their customers' needs in an economically efficient way and on an ongoing basis). ${ }^{26}$ Therefore, the common good of a company does not consist of its direct contribution to the common good of society (Kennedy, 2007, pp. 177-178), although the human goods it pursues contribute indirectly to that common good.

Business activity must at all times be compatible with the common good of society because "while we argue that business is not responsible for the common good, it is, like all communities, responsible to the common good" (Alford and Naughton, 2001, p. 41): it must not prevent it and, as far as possible, it must contribute to it (although this is more than just an indirect function). ${ }^{27}$

\footnotetext{
${ }^{25}$ As we already said, the common good of a company cannot consist of material goods, which cannot be shared (the company's physical or financial capital, its volume of production or sales, its market share, its stock market value, its profits or other similar variables), although these goods have a place in the process by which goods are produced in the company and contribute to the creation of the company's common good.

26 "Businesses should be characterized by their capacity to serve the common good of society through the production of useful goods and services. In seeking to produce goods and services according to plans aimed at efficiency and at satisfying the interests of the different parties involved, businesses create wealth for all of society (...). Besides this typically economic function, businesses also perform a social function, creating opportunities for meeting, cooperating and the enhancement of the abilities of the people involved. (...) A business' objective must be met in economic terms and according to economic criteria, but the authentic values that bring about the concrete development of the person and society must not be neglected" (Pontifical Council for Justice and Peace 2004, n. 338; my emphasis).

27 The common good of the company is likewise not to be identified with companies' contribution to solving social, human, environmental problems, etc., which are not their main purpose.
} 
In view of all the above, it seems to us that the common good of the company must meet the following requirements:

1. It must be a final good or a set of final (i.e., transcendent and immanent) goods, which is to say, qualities intrinsic to the person or perfections that take place in the person (knowledge, capabilities and/or virtues).

2. These goods, being final goods, are not directly oriented to satisfying needs (in the strict economic sense), but to accomplishing the purpose of the activity in question. They therefore enable people to do what they are called upon to do.

3. They must be common goods in terms of their use or participation; that is, they must be shareable or participable. This means they cannot be material goods.

4. They must be accessible to all who collaborate in the activity: all must benefit from them, at least potentially.

5. They must be produced through communal action: they are generated in human interactions within the organization or in pursuit of the organization's purpose (e.g., in interaction with the organization's customers).

6. Therefore, participating in creating these goods is to some extent a duty (and a right) of all people in the organization.

7. Those who participate in producing the common good of the company contribute personal or common extrinsic, intrinsic and transcendent goods. There is, therefore, a process of giving, or at least of exchange, in generating the common good of the company.

8. This common good is generated through human activities, whether manual or intellectual, managerial or operational.

9. These activities form part of companies' principal activity; in other words, they are not peripheral (as would be philanthropy or charity).

10. And as companies' principal activity is an economic activity, their common good must be generated in those same economic activities.

11. Being common in participation and communal in production, the common goods of companies are produced and used in the same act. For example, a person who acquires knowledge or virtue while working "produces" that good at the same time as he uses it, "invests" in it or "consumes" it.

12. Yet if these common goods are perfections of the person, they remain in the person in a lasting way, provided the person does not lose them. An agent who acquires knowledge or virtue may therefore use it again on another occasion.

13. The common good of the company is therefore a good oriented directly and principally at people and only indirectly at the organization.

14. Being common goods, they also have effects on other people in the organization: the knowledge acquired by one person may be shared by others, and the capabilities or skills and virtues acquired by one may benefit others (although they will not necessarily produce virtues in others, as this will depend on the others' freedom). 
15. Furthermore, these goods can be "used" outside the company and so can produce "externalities" in society as a whole. ${ }^{28}$ Already this is a form of cooperation with the common good of other communities and society at large.

16. The common good of a particular community is subordinate to the common good of society as a whole, insofar as the former makes the latter possible or at least does not impede it.

17. The common good of a particular community is therefore a particular good in contrast to the common good of society, insofar as those who are not part of the organization cannot share in it fully.

18. As companies are economic entities, they must meet the conditions of efficiency that economics demands of this type of activity.

In view of these requirements, what can the common good of a company consist of? We could say that it is the ordered set of transcendent (virtues) and intrinsic (knowledge and capabilities) goods generated in a company's activity (the production and distribution of goods and services). These are final and common goods, produced in the organization to satisfy human needs (objective dimension) through the cooperation of all members in the production process (subjective dimension) (Sison and Fontrodona, 2008, p. 28; Kangas, 1983, p. 130) in accordance with the (economic, social and moral) conditions of that process. ${ }^{29}$

We believe that the emphasis should be more on the "production" of the common good than on its "use" or "consumption": what contributes to the excellence or perfection of people is their participation in the production process, the joint activity, the pursuit of the common goal of the company, because it is that participation which generates the common good and perfects people. Similarly, what makes a company excellent is its ability to bring about that improvement in people precisely in the business of producing and selling goods and services to satisfy customers' needs. ${ }^{30}$

And although companies are a true "community of work" (Naughton et al., 1996; Alford and Naughton, 2001, p. 65; cf. Melé, 2002, p. 196), it is not only participation in work that generates the common good, as the owners of the means of production (capitalists, financiers, suppliers, etc.) also participate in producing it and so also may improve as people through their cooperation in this joint activity. ${ }^{31}$

\footnotetext{
${ }^{28}$ See Clarke and Lyons' (2007, pp. 275-278) critique of Grisez (1997, pp. 454-455), who limits the scope of the creation of the common good of the company to the company's stakeholders.

${ }^{29}$ The economic requirements ensure that the process is efficient; the social requirements, that it is attractive to the agents involved; and the ethical requirements, that decisions are consistent (Pérez López, 1993; Argandoña, 2008a, b, c).

${ }^{30}$ If "the organizational common good is the promotion of all the goods necessary for integral human development in the organization" (Alford and Naughton, 2001, p. 45; my emphasis), companies will be properly ordered to the common good if they promote those goods, even if they do not achieve them (e.g., because their employees, exercising their freedom, refuse to act virtuously).

31 That is why, as cooperators, these people have some degree of responsibility in the company's activity, honest or otherwise.
} 
As we pointed out earlier, material goods are an important part of the process of producing the common good, though not as material goods as such but on account of the giving, the attitude or the relationships they entail. "Products and services 'bring us into relationship with other people' (...) and can be the 'major means of integrating us into a community, of giving us a place, status, belonging and value'. They are a means of binding us together in mutual concern and mutual service, and a crucial part of promoting and preserving the common good" (Alford and Naughton, 2001, p. 184, quoting Ike, 1986, pp. 243-244). The common good does not lie in them, however, but "in their production as the joint effort of work of a group of human beings. That production, joint activity or work in common, then, is the reason people come together and constitute the firm as an intermediate community" (Sison and Fontrodona, 2008, p. 22), although it seems to us that the common good is not the production activity itself but the common goods generated in that activity.

\section{Conclusions}

The theory of the firm has been subjected to criticisms in recent years that call for a revision of its anthropological assumptions (Ferraro et al., 2005; Ghoshal, 2005; Melé, 2008; Rocha and Ghoshal, 2006). The philosophy that originates in Aristotle (1941) and Thomas Aquinas (1981) is an excellent candidate for conducting that revision on account of the breadth of its conception of man and its implications for organization theory. An important part of this philosophy is the concept of common good, developed initially for human society as a whole or in its political dimension but equally applicable to institutions of lesser scope such as companies. In this study we have developed the concept of common good starting from the general concept of good, as a link between the philosophical and the economic conceptions of human action, showing how the concept of common good may be used in a broad, wellfounded theory of the firm. 


\section{References}

Alford, H. J. and M. J. Naughton (2001), "Managing as if Faith Mattered," Notre Dame, IN, University of Notre Dame Press.

Alford, H. J. and M. J. Naughton (eds.), (2002), "Beyond the shareholder model of the firm: Working toward the common good of business," in S. A. Cortright and M. J. Naughton (eds.), "Rethinking the Purpose of Business. Interdisciplinary Essays from the Catholic Social Tradition”. Notre Dame, IN, University of Notre Dame Press, pp. 23-47.

Alford, H. J. and Y. Shcherbinina (2008), "Corporate social responsibility and common good," in E. Bettini and F. Moscarini (eds.), "Responsabilità Sociale d'Impresa e Nuovo Umanesimo". Genoa, San Giorgio Editrice, pp. 14-30.

Aquinas, Thomas (1950), "The Religious State, the Episcopate and the Priestly Office: A Translation of the Minor Work of the Saint on the Perfection of the Spiritual Life," Westminster, MD, Newman.

Aquinas, Thomas (1981), “Summa Theologica,” New York, NY, Christian Classics.

Argandoña, A. (1998), "The stakeholder theory and the common good," Journal of Business Ethics, 17, pp. 1093-1102.

Argandoña, A. (2003), "Preferencias y aprendizajes," in "De Computis et Scripturis. Estudios en Homenaje a Mario Pifarré Riera”. Barcelona, Real Academia de Ciencias Económicas y Financieras, pp. 51-77.

Argandoña, A. (2005a), "La teoría de la acción y la teoría económica," in R. Rubio de Urquía, E. M. Ureña and F. F. Muñoz Pérez (eds.), "Estudios de Teoría Económica y Antropología”, Madrid, Unión Editorial, pp. 615-646.

Argandoña, A. (2005b), "Los economistas y el bien común," in “Doctor Mario Pifarré Riera: La ciencia de la contabilidad", Barcelona, Publicacions i Edicions de la Universitat de Barcelona, pp. 59-72.

Argandoña, A. (2008a), "Integrating ethics into action theory and organizational theory," Journal of Business Ethics, 78, pp. 435-446.

Argandoña, A. (2008b), "Consistency in decision making in companies," presented at the Seminar "Humanizing the Firm and the Management Profession," Barcelona, IESE Business School, June 30-July 2.

Argandoña, A. (2008c), "Anthropological and ethical foundations of organization theory," in S. Gregg and J. R. Sonter (eds.), "Rethinking Business Management. Examining the Foundations of Business Education”, Princeton, NJ, Witherspoon Institute, pp. 38-49.

Ariño, M. A. (2005), “Toma de decisiones y gobierno de organizaciones,” Barcelona, Deusto.

Aristotle (1941), “The Basic Works of Aristotle. Ethica Nicomachea," New York, NY, Random House.

Arjoon, S. (2000), "Virtue theory as a dynamic theory of business," Journal of Business Ethics, 28, pp. 159-178.

Clarke, L. L. and E. C. Lyons (2007), "The corporate common good: The right and obligation of managers to do good to others," University of Dayton Law Review, 32, 2, pp. 273-299. 
Donaldson, L. (2002), "Damned by our own theories: Contradictions between theories and management education," Academy of Management Learning and Education, 1 (1), pp. 96-106.

Ferraro, F., J. Pfeffer and R. I. Sutton (2005), "Economic language and assumptions: How theories can become self-fulfilling," Academy of Management Review, 30, pp. 8-24.

Finnis, J. (1983), “Fundamentals of Ethics,” Oxford, Clarendon Press.

Fontrodona, J. and A. J. G. Sison (2006), "The nature of the firm, agency theory and shareholder theory: A critique from philosophical anthropology," Journal of Business Ethics, 66, pp. 33-42.

Gates, J. (2002), "Reengineering ownership for the common good," in S. A. Cortright and M. J. Naughton (eds.), "Rethinking the Purpose of Business. Interdisciplinary Essays from the Catholic Social Tradition”, Notre Dame, IN, University of Notre Dame Press, pp. 264-288.

Ghoshal, S. (2005), "Bad management theories are destroying good management practices," Academy of Management Learning and Education, 4 (1), pp. 75-91.

Grisez, G. (1997), “The Way of the Lord Jesus," Vol. 3: "Difficult Moral Questions”, Quincy, IL, Franciscan Press.

Ike, 0. (1986), "Value, Meaning, and Social Structure of Human Work," Frankfurt am Main, Peter Lang.

John Paul II (1991), “Encyclical Letter 'Centesimus annus', in Acta Apostolicae Sedis”, p. 83.

Kangas, J. E. (1983), "Compatible human communities: The role of ethics in modern enterprise," Journal of Business Ethics, 2, pp. 127-133.

Kennedy, R. G. (2007), "Business and the common good," in P. Booth, ed., "Catholic Social Teaching and the Market Economy”, London, Institute of Economic Affairs, pp. 164-189.

Koslowski, P. (2006), "The common good of the firm as the fiduciary duty of the manager," in G. J. Roussouw and A. J. Sison (eds.), "Global Perspective on Ethics of Corporate Governance". New York, Palgrave.

MacIntyre, A. (1988), “Whose Justice? Which Rationality?,” London, Duckworth.

MacIntyre, A. (1990), "Three Rival Versions of Moral Enquiry. Encyclopaedia, Genealogy and Tradition," Notre Dame, IN, University of Notre Dame Press.

Mahon, J. F. and R. A. McGowan (1991), "Searching for the common good: A process-oriented approach,” Business Horizons, 34 (4), pp. 79-86.

Mankiw, N. G. (1998), “Principles of Economics,” New York, NY, Harcourt Brace \& Co.

Melé, D. (2002), "Not only stakeholder interests: The firm oriented toward the common good," in S. A. Cortright and M. J. Naughton (eds.), "Rethinking the Purpose of Business. Interdisciplinary Essays from the Catholic Social Tradition", Notre Dame, IN, University of Notre Dame Press, pp. 190-214.

Melé, D. (2008), "Three current views of the firm and its purpose. Toward a more complete model," presented at the Seminar "Humanizing the Firm and the Management Profession," Barcelona, IESE Business School, June 30-July 2. 
Naughton, M. J. (2004), "The common good and the purpose of the firm: A critique of the shareholder and stakeholder models from the Catholic social tradition," www.stthomas.edu/cathstudies/faculty/Naughton/cgood.htm

Naughton, M. J. (2006), "The corporation as a community of work: Understanding the firm within the Catholic social tradition," Ave Maria Law Review, 4, 1, pp. 33-75.

Naughton, M. J., H. J. Alford and B. Brady (1995), "The common good and the purpose of the firm," Journal of Human Values, 1 (2) (1995), pp. 221-37.

Pérez López, J. A. (1991), "Teoría de la acción humana en las organizaciones. La acción personal," Madrid, Rialp.

Pérez López, J. A. (1993), “Fundamentos de la Dirección de Empresas,” Madrid, Rialp.

Pontifical Council for Justice and Peace (2004), "Compendium of the Social Doctrine of the Church," Vatican City, Libreria Editrice Vaticana.

Putnam, R. (2000), "Bowling Alone: The Collapse and Revival of the American Community," New York, NY, Simon and Schuster.

Rocha, H. O. and S. Ghoshal (2006), "Beyond self-interest revisited," Journal of Management Studies, 43 (3), pp. 585-619.

Rosanas, J. M. (2008a), "Beyond economic criteria: A humanistic approach to organizational survival,” Journal of Business Ethics, 78, pp. 447-462.

Rosanas, J. M. (2008b), "Managerial action in organizational context: The need for multicriteria decision-making," presented at the Seminar "Humanizing the Firm and the Management Profession,” Barcelona, IESE Business School, June 30-July 2.

Second Vatican Council (1965), "Pastoral Constitution Gaudium et Spes," in Acta Apostolicae Sedis, p. 58.

Shionoya, Y. (2008), "Economic ethics: A systematic integration," in C. Cowton and M. Haase (eds.), "Trends in Business and Economic Ethics”, Berlin, Springer Verlag, pp. 71-89.

Sison, A. J. G. (2003), “The Moral Capital of Leaders,” Northampton, MA, Edward Elgar.

Sison, A. J. G. and J. Fontrodona (2008), "The common good of the firm in the AristotelianThomistic tradition," presented at the Seminar "Humanizing the Firm and the Management Profession,” Barcelona, IESE Business School, June 30-July 2.

Stebbins, J. M. (1997), “Business, faith, and the common good,” Review of Business, 19 (1), pp. 5-8. Yuengert, A. M. (2001), “The common good for economists," Faith and Economics, 38, pp. 1-9. 